\title{
Assessing the Organic Pollution and Aquaculture Activity of Surface water at Shatt-Al-Arab Estuary Southern of Iraq
}

\author{
Makia M. Al-Hejujeㄹ, Hamid T. Al-saad ${ }^{2}$ and Najah A. Hussain ${ }^{1}$ \\ ${ }^{1}$ Department of Ecology, College of Sciences, University of Basrah, Iraq. \\ ${ }^{2}$ Department of Marine Chemistry, Marine Science Center, University of Basrah, Iraq \\ Email: htalsaad@yahoo.com
}

\begin{abstract}
Surface water samples were collected monthly from December, 2012 to November, 2013 at the middle part of Shatt Al-Arab Estuary at Basrah city during the low tide period to assess the organic pollution status using the Organic Pollution Index (OPI), and the aquaculture activities using Minimum Operator Concept (MOC). Results of biological oxygen demand $\left(B O D_{5}\right)$, ammonium, nitrite and orthophosphate were used to calculate OPI, while dissolved oxygen (DO), total phosphate and turbidity were used to calculate MOC. Results showed that OPI values range from 4.5 - 4.75 referred to weak organic-non organic pollution status. On the other hand, the water of Shatt Al-Arab Estuary can be considered as medium-excellent water for aquaculture activity according to the MOC range (66.67 - 93.33).
\end{abstract}

Keywords: Estuary, Surface water, Organic Pollution Index, Aquaculture activity, Minimum Operator Concept

\section{Introduction}

Shatt Al-Arab Estuary is the main source of fresh water at Basrah city southern Iraq, which play an important role in various sectors of economy such as agricultural, industrial activities, power plants, livestock production, fisheries and other creative activities. River play a major role in assimilation or transporting municipal and industrial wastewater and runoff from agricultural land. Municipal and industrial wastewater discharge constitutes a constant polluting source, whereas surface runoff is a seasonal phenomenon, largely affected by climate within the area. Estuary has been put under tremendous pressure and have been deteriorated due to various sources like increasing urbanization, industrialization, and agricultural activities (AlHejuje, 2014; Krika and Krika, 2017).

In future to protect water bodies from pollution, it is required to keep watching to stop the expected pollution. For water bodies it is necessary to find out some pollution monitoring tools (Chougule et al., 2009). An effective tool which is used to assess the water quality and suitability for different purposes uses is the water quality Indices that included different models, considered as effective tools. These tools act as a bridge between professionals and the laymen or decision makers (CCME, 2001).
Organic Pollution Index (OPI) is one of the most important tools which has been previously proposed to assess the temporal and seasonal contamination with the organic pollutants (Benkhedda et al., 2014). Four parameters (Biological Oxygen Demand (BOD5), Ammonium $\left(\mathrm{NH}_{4}\right)$, Nitrite $\left(\mathrm{NO}_{2}\right)$ and Reactive Phosphorous $\left(\mathrm{PO}_{4}\right)$ ) were chosen to calculate this index .Such water pollution index gives an idea about the increase or decrease in pollution rate for the water body under consideration. Water pollution index is accurate and timely information to observe water quality (Chougule et al., 2009).

Minimum Operator Concept (MOC) is another water pollution index composed of three measurable environmental parameters (turbidity (Turbi.), Total Phosphate (TP), and Dissolved Oxygen (DO), concentrations of these parameters were normalized on a scale from 0-100, and translated into statements of water quality. The degradation in water from aquaculture activity can be easily inferred with this index on only three parameters which is used to evaluate the presence of aquaculture activities (e.g. fish farming activities). This tool is important because it decreases the cost of monitoring programs and/or the expenses associated with the implantation of one (Simões et al., 2008). 
Surface waters quality evaluation in Basrah city is usually practiced by physicochemical measurements and biological indicators assessment are rarely performed. However, the objective of the present study was to determine the temporal and spatial variations of some environmental conditions and to assess the organic pollution status and aquaculture activities at the Shatt Al-Arab estuary using OPI and MOC indices. Also, to highlight the present status of Shatt Al-Arab estuary to the administration and decision makers.

\section{Materials and Methods}

Tigris and the Euphrates estuary confluence Shatt Al-Arab estuary at Qurna town north of Basrah city southern Iraq. The estuary has a length of $195 \mathrm{~km}$, and width varies at different point from $0.35 \mathrm{~km}$ at Basrah city to $1.5 \mathrm{~km}$ at its mouth in Fao town. Weather record extremely hot in summer and cold with fluctuated rain in winter, temperature ranged from 13.0-33.40 (Al-Hejuje, 2014).

Five stations (30.36 $623 \mathrm{~N}$ and 47.45662 E (station 1); $30.34915 \mathrm{~N}$ and $47.46368 \mathrm{E}$ (station 2); $30.33755 \mathrm{~N}$ and $47.47563 \mathrm{E}$ (station 3); $30.30376 \mathrm{~N}$ and $47.51328 \mathrm{E}$ (station 4); and $30.27251 \mathrm{~N}$ and $48.02810 \mathrm{E}$ (station 5), was monitored on monthly basis at the middle part of Shatt Al-Arab Estuary from December, 2012 to November, 2013. At each site, two samples at the top depth of $0.20-0.30 \mathrm{~m}$ were obtained to quantify physical-chemical parameters. Water samples were collected during the low tide period.

Turbidity was measured in the field using turbidity meter (Lovibond-Turbi Direct). DO and $\mathrm{BOD}_{5}$ was measured according to Azid modification
Winkler method (Lind, 1979), while nitrite $\left(\mathrm{NO}_{2}\right)$ measured by using spectrophotometry (APHA, 2005). Total Phosphate (TP) was digested according to APHA (2005), then TP and $\mathrm{PO}_{4}$ were determined spectrophotometry according to (Strickland and Parsons, 1972). Ammonium-N was measured using the macro-Kjeldahl and titration method (APHA, 2005).

\section{Organic Pollution Index (OPI)}

The OPI was calculated based on Guasmi et al. (2010) as the average number of classes of four properties $\left(\mathrm{BOD}_{5}, \mathrm{NH}_{4}, \mathrm{NO}_{2}, \mathrm{PO}_{4}\right)$. The class limits of pollutants and the grid evaluation of organic pollution types were showed at Table 1 and 2.

\section{Minimum Operator Concept (MOC)}

The index proposed in this work is composed of three measurable environmental parameters i.e. turbidity, total phosphorus and dissolved oxygen. Concentrations of these three variables were normalized on a scale from 0 to 100 according to Pesce and Wunderlin (2000) and translated into statements of water quality (excellent, good, regular, fair and poor).This index is used to evaluate the presence of aquaculture activities.

Where:

$$
\mathrm{MOC}=\left(\mathrm{C}_{\mathrm{DO}}+\mathrm{C}_{\text {totP. }}+\mathrm{C}_{\text {Tubid. }}\right) / 3
$$

$\mathrm{C}_{\mathrm{DO}}$ : is the value due to dissolved oxygen after normalization.

Ctotp: is the value due to total phosphate after normalization.

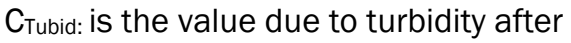
normalization.

After calculation value, classified according to NSFWQI. Rating as in Table 4.

Table 1. Class limits of pollutants (Leclercq and Maquet, 1987)

\begin{tabular}{ccccc}
\hline Classes & BOD5 $\left(\mathrm{mg} . \mathrm{L}^{-1}\right)$ & Ammonium $\left(\mathrm{mg} \mathrm{N.L^{-1 } )}\right.$ & Nitrites $\left(\mu \mathrm{g}{\left.\mathrm{N} . \mathrm{L}^{-1}\right)}^{-1}\right.$ & Phosphates $(\mu \mathrm{g}$ P.L-1) \\
\hline 5 & $<2$ & $<0.1$ & $\leq 5$ & $\leq 15$ \\
4 & $2-5$ & $0.1-0.9$ & $6-10$ & $16-75$ \\
3 & $5.1-10$ & $1.0-2.4$ & $11-50$ & $76-250$ \\
2 & $10.1-15$ & $2.5-6$ & $51-150$ & $251-900$ \\
1 & $>15$ & $>6$ & $>150$ & $>900$ \\
\hline
\end{tabular}

Table 2. Grid evaluation of organic pollution types

\begin{tabular}{cc}
\hline Limits & Organic pollution level \\
\hline $5.0-4.6$ & None \\
$4.5-4.0$ & Weak \\
$3.9-3.0$ & Moderate \\
$2.9-2.0$ & Strong \\
$1.9-1.0$ & Very strong \\
\hline
\end{tabular}


Table 3. Normalization factors for MOC index

\begin{tabular}{|c|c|c|c|c|c|c|c|c|c|c|c|}
\hline \multirow{2}{*}{ Parameters } & \multicolumn{11}{|c|}{ Normalization factor } \\
\hline & 100 & 90 & 80 & 70 & 60 & 50 & 40 & 30 & 20 & 10 & 0 \\
\hline $\begin{array}{c}\text { Dissolved } \\
\text { oxygen (mg.L-1) }\end{array}$ & $\geq 7.5$ & $\geq 7.0$ & $\geq 6.5$ & $\geq 6.0$ & $\geq 5.0$ & $\geq 4.0$ & $\geq 3.5$ & $\geq 3.0$ & $\geq 2.0$ & $\geq 1.0$ & $<1.0$ \\
\hline $\begin{array}{l}\text { Total } \\
\text { phosphorus } \\
\text { (mg.L-1) }\end{array}$ & $<0.05$ & $<0.05$ & $<0.05$ & $<0.10$ & $<0.10$ & $<0.15$ & $<0.15$ & $<0.20$ & $<0.20$ & $<0.30$ & $<0.30$ \\
\hline Turbidity (NTU) & $<5$ & $<10$ & $<15$ & $<20$ & $<25$ & $<30$ & $<40$ & $<60$ & $<80$ & $\leq 100$ & $>100$ \\
\hline
\end{tabular}

\section{Statistical Analysis}

Analysis of variance was applied by Minitab ver.16 software and Relative Least Significant Differences (RLSD) values were calculated to identify the existence of temporal and spatial significant differences. Principal Components Analysis (PCA) was done in order to get an overall assessment of the possible relations among environmental variables, where each arrow points in the direction of steepest which indicates the increase of values for the corresponding variable .The angles between arrows indicate the sign of the correlation between the variables. When the angle is sharp, the correlation is positive and when the angle is larger than $90^{\circ}$, the correlation is negative.

Table 4. Classification criteria standard based on NSFWQI .Rating. (Samantray et al., 2009)

\begin{tabular}{cc}
\hline MOC Value & Descriptor \\
\hline $91-100$ & Excellent \\
$71-90$ & Good water \\
$51-70$ & Medium water \\
$26-50$ & Bad water \\
$0-25$ & Very bad water \\
\hline
\end{tabular}

\section{Results and Discussion}

Measured parameters were subjected to univariate descriptive statistical analysis (mean, standard deviation, minimum and maximum) Table (5) and multivariate statistical methods. In order to establish a relationship between the various physicochemical parameters and to better evaluate the effect of anthropogenic activities on the quality of surface water.

Evaluation of dissolved oxygen is crucial to the survival of aquatic organisms (Kouame et al., 2012). Water flow of the estuary is causing oxygen dissolve in water. Additional oxygen is provided by aquatic plants producing oxygen during the day. Highest dissolved oxygen value (11.15 mg.L-1) was detected at station 1 in January, while lowest value
(3.1 mg.L-1) was at station 4 in September (Table 5). Significant differences $(P<0.05)$ were found among stations, the highest mean value (7.46 mg. L $^{-1}$ ) of DO recorded at station 1 , while the lowest mean value (4.99 mg. L $^{-1}$ ) was recorded at station 4 , a reduction in the dissolved oxygen value in the downstream zone (Station 4) of the discharge point when compared with the upstream (station 1) is indicative of enormous amount of organic loads which required high level of oxygen for chemical oxidation and decomposition. Also, seasonal significant differences $(P<0.01)$ were found. In general, for the five sites, the oxygen content decreases during the warm period, as more water is heated, less oxygen is soluble, the lowest values (5.397 and 5.47 mg. $\mathrm{L}^{-1}$ ) was recorded in summer and autumn, respectively, while the highest mean value (8.06 mg.L-1) of DO was recorded in winter .

Biological Oxygen Demand $\left(\mathrm{BOD}_{5}\right)$ values were fluctuated during the studied period with highest value (3.6 mg. $\mathrm{L}^{-1}$ ) recorded in March at station 2, while the value not detectable (ND) at most stations during different periods (Table 5). Non - significant differences $(P>0.05)$ were found among seasons or among stations. $\mathrm{BOD}_{5}$ gives an estimate of anthropogenic amount and natural biodegradable organic matter. In Shatt Al-Arab estuary, the values of $\mathrm{BOD}_{5}$ is due to the amounts of waste water rich in organic matter from urban and agricultural activities (AL-Hejuje, 1997). Simões et al. (2008) showed that high levels of $\mathrm{BOD}_{5}$ refers to untreated sewage (especially from aquaculture activity) discharged near the sampling points. Low concentration of $\mathrm{BOD}_{5}$ recorded during this study may be due to huge volume of fresh water that diluted the organic matters resulting in the decrease of the BOD5 values, this explanation was in agreement with Samantray et al. (2009).

The highest value of turbidity recorded in December (140 NTU) at station 5, and the lowest value (8.13 NTU) recorded in February at station 2 (Table 5). Non-Significant differences $(P>0.05)$ were found among seasons, but significant differences $(P<0.01)$ were found among stations, 
the highest mean value (48.00 NTU) was recorded at station 5 and this may be caused by Karon estuary which has turbid water discharged to Shatt Al-Arab close to this station, whereas the lowest mean value (14.77 NTU) recorded at station 4 because the low velocity of water at this station .The high turbidity during Autumn season may be due to the addition of large amounts of sewage wastes from the surrounding area, or may be due to the growing of aquatic vegetation or by the lowering of the volume of water, this finding was in agreement with Pradeep et al. (2012). Also, turbidity values increased in autumn season may be as a result of decomposition processing occurring in sediments.

Nitrite concentration ranged from $(0.52 \mu \mathrm{g} . \mathrm{L}$ 1) in October at station 1 to (11.26 $\left.\mu \mathrm{g} . \mathrm{L}^{-1}\right)$ in August at station 4 (Table 5). The nitrite concentration was generally low at all stations. However, these lower values of nitrite could affect the fish health and quality because water containing nitrites can be considered suspicious or even toxic to fish at low quantity .The presence of nitrite is an indicator of wastewater pollution in water (Varol et al., 2011). Non-significant differences $(P>0.05)$ among seasons were found, whereas, significant differences $(P<0.01)$ were found among stations, the highest mean value $\left(6.72 \mu \mathrm{g} . \mathrm{L}^{-1}\right)$ was observed at station 4 , while the lowest mean value ( 1.23 $\left.\mu g . \mathrm{L}^{-1}\right)$ was observed at station 1 . Nitrites come either from incomplete ammonium ions oxidation, or a nitrate reduction.

The ammonium values ranged from $(0.28$ mg.L-1) in varied periods at all stations to (3.08 mg. $\mathrm{L}^{-1}$ ) in February at station 1 (Table 5). Significant differences $(P<0.01)$ were found among seasons, the highest mean value $\left(1.79{\left.\mathrm{mg} . \mathrm{L}^{-1}\right)}^{-1}\right.$ in winter, while the lowest mean value $\left(0.56 \mathrm{mg} . \mathrm{L}^{-1}\right)$ was recorded in summer and Autumn. In contrast, non-significant differences $(P>0.05)$ were found among stations. The highest values were recorded in sites receiving waste water loaded with organic nitrogenous material. During Winter, ammonium excess is observed at all stations of the estuary, this can be caused by a nitrogen fertilizers contribution, Most fish and invertebrates excrete ammonia as their principle nitrogenous waste (Buttner et al., 1993), therefore, ammonia in the present study has different pattern compared with the other nitrogenous compounds, and low values

Table 5. The values (means, Standard Deviation (SD) and ranges (min.- max.) of parameters at the studied stations.

\begin{tabular}{|c|c|c|c|c|c|c|}
\hline Parameters & & Station 1 & Station 2 & Station 3 & Station4 & Station 5 \\
\hline & Mean & 7.46 & 6.59 & 6.46 & 4.99 & 6.77 \\
\hline \multirow[t]{3}{*}{ DO (mg.L-1) } & SD & 1.49 & 1.88 & 1.91 & 1.78 & 1.00 \\
\hline & Range & 5.80-11.15 & $4.80-10.40$ & $4.50-10.30$ & 3.10- 9.50 & $5.00-8.85$ \\
\hline & Mean & 1.26 & 1.01 & 1.29 & 0.95 & 1.16 \\
\hline \multirow[t]{3}{*}{$\mathrm{BOD}_{5}\left(\mathrm{mg} . \mathrm{L}^{-1}\right)$} & SD & 0.63 & 0.94 & 0.83 & 0.68 & 0.66 \\
\hline & Range & $0.35-3.00$ & ND-3.60 & ND-2.90 & ND- 1.95 & ND-2.25 \\
\hline & Mean & 23.19 & 19.31 & 19.35 & 14.77 & 48.00 \\
\hline \multirow[t]{3}{*}{ Turbi. (NTU) } & SD & 13.17 & 6.52 & 7.47 & 4.36 & 33.83 \\
\hline & Range & $9.30-57.90$ & $8.13-27.00$ & $8.38-32.40$ & $8.75-24.20$ & $19.50-140.00$ \\
\hline & Mean & 1.23 & 2.41 & 3.29 & 6.72 & 3.62 \\
\hline \multirow[t]{3}{*}{$\mathrm{NO}_{2}\left(\mu \mathrm{g}-\mathrm{N} \cdot \mathrm{L}^{-1}\right)$} & SD & 0.82 & 1.51 & 2.08 & 3.25 & 1.98 \\
\hline & Range & $0.52-3.48$ & $1.02-6.06$ & $0.95-8.00$ & 0.93-11.26 & 1.24- 7.15 \\
\hline & Mean & 1.02 & 0.89 & 0.89 & 0.77 & 1.05 \\
\hline \multirow[t]{3}{*}{$\mathrm{NH}_{4}\left(\mathrm{mg}-\mathrm{N} \cdot \mathrm{L}^{-1}\right)$} & SD & 0.76 & 0.77 & 0.61 & 0.49 & 0.68 \\
\hline & Range & $0.28-3.08$ & $0.28-2.52$ & $0.28-2.24$ & $0.28-1.96$ & $0.28-2.24$ \\
\hline & Mean & 1.25 & 1.90 & 2.25 & 3.52 & 1.32 \\
\hline \multirow[t]{3}{*}{$\mathrm{PO}_{4}\left(\mu \mathrm{g}-\mathrm{P} . \mathrm{L}^{-1}\right)$} & SD & 1.02 & 1.32 & 1.44 & 1.77 & 0.97 \\
\hline & Range & $0.42-4.27$ & $0.86-5.45$ & $0.91-5.91$ & $1.68-8.05$ & $0.33-3.68$ \\
\hline & Mean & 14.58 & 18.21 & 12.12 & 18.26 & 16.12 \\
\hline \multirow[t]{2}{*}{ TP $\left(\mu g-P . L^{-1}\right)$} & SD & 11.09 & 11.24 & 5.88 & 15.34 & 13.02 \\
\hline & Range & 3.24-41.11 & 4.75-39.92 & 4.19- 23.67 & $5.52-51.00$ & $4.27-52.16$ \\
\hline
\end{tabular}

ND: Not Detectable 
Table 6. The MOC and OPI values and the status descriptions at the studied stations during the studied periods.

\begin{tabular}{|c|c|c|c|c|c|}
\hline Stations & Season & MOC Value & Descriptions & OPI Values & Descriptions \\
\hline \multirow[t]{4}{*}{ Station 1} & Winter & 93.33 & Excellent Water & 4.5 & Weak Organic Pollution \\
\hline & Spring & 90 & Good Water & 4.75 & Non- Organic Pollution \\
\hline & Summer & 70 & Medium Water & 4.75 & Non- Organic Pollution \\
\hline & Autumn & 76.67 & Good Water & 4.75 & Non- Organic Pollution \\
\hline \multirow[t]{4}{*}{ Station 2} & Winter & 93.33 & Excellent Water & 4.5 & Weak Organic Pollution \\
\hline & Spring & 83.33 & Good Water & 4.75 & Non- Organic Pollution \\
\hline & Summer & 73.33 & Good Water & 4.75 & Non- Organic Pollution \\
\hline & Autumn & 73.33 & Good Water & 4.75 & Non- Organic Pollution \\
\hline \multirow[t]{4}{*}{ Station 3} & Winter & 93.33 & Excellent Water & 4.5 & Weak Organic Pollution \\
\hline & Spring & 86.67 & Good Water & 4.75 & Non- Organic Pollution \\
\hline & Summer & 73.33 & Good Water & 4.75 & Non- Organic Pollution \\
\hline & Autumn & 70 & Medium Water & 4.75 & Non- Organic Pollution \\
\hline \multirow[t]{4}{*}{ Station 4} & Winter & 86.67 & Good Water & 4.5 & Weak Organic Pollution \\
\hline & Spring & 80 & Good Water & 4.5 & Weak Organic Pollution \\
\hline & Summer & 73.33 & Good Water & 4.5 & Weak Organic Pollution \\
\hline & Autumn & 66.67 & Medium Water & 4.5 & Weak Organic Pollution \\
\hline \multirow[t]{4}{*}{ Station 5} & Winter & 73.33 & Good Water & 4.5 & Weak Organic Pollution \\
\hline & Spring & 76.67 & Good Water & 4.5 & Weak Organic Pollution \\
\hline & Summer & 70 & Medium Water & 4.75 & Non- Organic Pollution \\
\hline & Autumn & 66.67 & Medium Water & 4.75 & Non- Organic Pollution \\
\hline
\end{tabular}

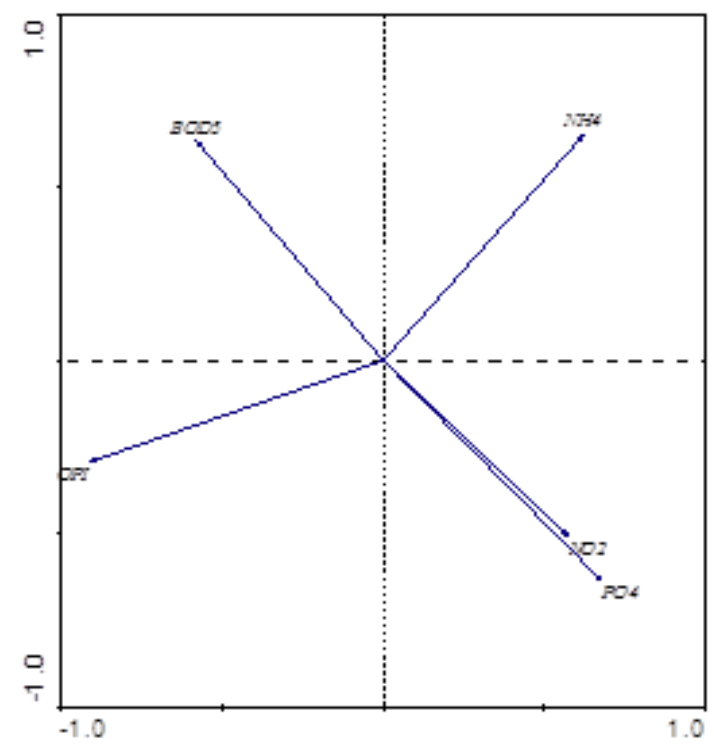

Figure 1. The PCA analysis between OPI and its correlated variables

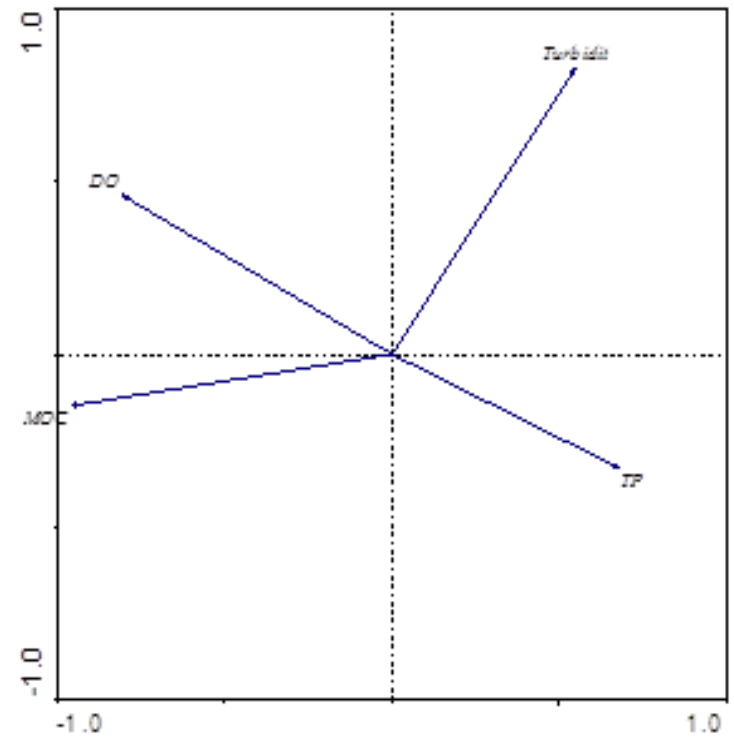

Figure 2. The PCA analysis between MOC and its correlated variables 
of ammonia at some stations (such as station 4) may be due to the least availability of fish and invertebrate present at this polluted station.

The highest value of reactive phosphate was (8.05 $\left.\mu \mathrm{g} . \mathrm{L}^{-1}\right)$ detected in December at station 4, while the lowest value $\left(0.3305 \mu \mathrm{g} . \mathrm{L}^{-1}\right)$ was detected in May at station 5 (Table 5). Significant differences $(P<0.05)$ were found among seasons, the highest mean value $\left(2.65 \mu \mathrm{g} . \mathrm{L}^{-1}\right)$ was recorded in winter, while the lowest mean value $(1.21 \mathrm{mg}$. $\left.\mathrm{m}^{-3}\right)$ recorded in Spring. Also, significant differences $(P<0.01)$ were found among stations , the highest mean value (3.52 $\left.\mu \mathrm{g} . \mathrm{L}^{-1}\right)$ was recorded at station 4 , while the lowest mean value (1.25 $\left.\mu g . L^{-1}\right)$ was recorded at station 1 . Orthophosphate lowest concentrations characterize the station 1 that does not receive municipal wastewater discharges, which is more distant from the discharge points of effluents, or may be due to the self-purifier capacity of the receiving stream at this station, this conclusion was in agreement with Kouame et al. (2012). Whereas the highest levels were recorded at station 4 due to the waste water discharges loaded with organic matter received at this station.

The highest value of total phosphate was (52.16 $\mu \mathrm{g} . \mathrm{L}^{-1}$ ) in November at station 5, while the lowest value (3.24 $\mu$ g. $\left.\mathrm{L}^{-1}\right)$ was detected in March at station 1 (Table 5). Significant differences $(P<0.01)$ were found among seasons, the highest mean value (24.49 $\left.\mu \mathrm{g} . \mathrm{L}^{-1}\right)$ was recorded in autumn, while the lowest mean value (10.94 $\left.\mu \mathrm{g} . \mathrm{L}^{-1}\right)$ was recorded in winter. Whereas, non- significant differences $(P>0.05)$ were found among stations.

High levels of phosphates and other nutrients encourage eutrophication which could further deplete the dissolved oxygen levels of the estuary (Kouame et al., 2012). In addition, nutrients (nitrites and phosphates) may be diluted as they are washed downstream by current. However, the results show that there was pollution of the estuary's zone downstream the discharge point.

\section{Organic Pollution Index (OPI)}

The lowest value of OPI (4.5, Weak organic pollution) was recorded at all stations in different seasons, while the highest value $(4.75$, non- organic pollution) was recorded at all stations (except station 4 ) in the other seasons (Table 6). Significant differences $(P<0.05)$ were found among seasons, the highest mean value (4.70)was found in Summer and Autumn, Whereas the lowest mean value(4.50) was found in Winter. Rahul et al. (2013) showed that decay and decomposition of biological species may further increase the organic pollution load. Nonsignificant differences $(P>0.05)$ were found among stations. The PCA analysis was used to extract significant principal components (PCs) and further reduce the contribution of variables with minor significance and to give more interpretable results ( Baran and Warry, 2008). PCA analysis (Fig. 1) showed the correlations between the OPI and its variables.

\section{Minimum Operator Concept (MOC)}

The lowest value (66.6, Medium Water) was recorded at stations 4 and 5 in autumn, while the highest value (93.33, Excellent Water) was recorded at stations 1, 2 and 3 in winter (Table 6). Significant differences $(P<0.01)$ were found among seasons, the highest mean value (88.00) was found in Winter, while the lowest mean value (70.67) was found in autumn. Temporal significant differences from excellent water quality in winter to medium water quality in autumn may be due to the increasing values of DO, and decreasing values of TP in winter which increased the index value. While the low quality in autumn may be due to decreased DO values, and increased Turbidity and TP values. Nonsignificant differences $(P>0.05)$ were found among stations. PCA analysis (Fig.2) showed the correlations between the $\mathrm{MOC}$ and its variables.

\section{Conclusion}

Results revealed that water quality of Shatt AlArab Estuary is generally affected by the agricultural activities and dense population residing at banks. Therefore, it can be summarized that the control of point sources as well as non-point sources (such as from the agricultural fields, municipal effluents, direct human and animal bathing in the estuary, etc.) can be improve the water quality. According to OPI values the water of Shatt Al-Arab Estuary can be classify as weak organic polluted to non-organic pollute, and according to MOC values the water can be classify as medium to excellent water for aquaculture activities. The best quality was found in the upper site at Al-Mohamadiyat region (station 1 ) and the worst at the lower site at AlBradhiya region (station 4). Thus, the study illustrates the useful application of Organic Pollution Index (OPI) and Minimum Operator Concept (MOC) for the interpretation of surface water quality data and identification based on pollution status. 


\section{References}

Al-Hejuje, M.M. 1997. Distribution of Heavy Elements in Water and Sediments from AlAshar and Al-Khandak Canals Connected with Shatt Al Arab River and their Effects on Algae. M.Sc. Thesis. University of Basrah, College of Science, Biology Department, 104 pp.

Al-Hejuje, M.M. 2014. Application of Water Quality and Pollution Indices to Evaluate the Water and Sediments Status in the Middle Part of Shatt Al-Arab River. Ph.D. Thesis. University of Basrah, College of Science, Biology Department. 240 pp.

APHA: American Public Health Association. 2005. Standard methods for the examination of water and waste water, 21st Edition. Washington, DC. USA.

Baran , E. \& Warry, F. 2008. Simple Data Analysis for Biologists. World Fish Center and the Fisheries Administration. Phnom Penh, Cambodia. 67 pp.

Benkhedda, B., Belguermi, A., Tayeb, A., EL-Amine, B.M., Fethi, D. \& Youssouf, M. 2014. Organic Pollution Assessment and Biological Quality of the Estuary Oued Rhiou (Algeria). Int. J. Sci. Basic App. Res. 18 (1): 33-44.

Buttner, J.K., Soderberg, R.W. \& Terlizzi, D.E. 1993. An introduction to water chemistry in freshwater aquaculture. In (Northeastern Regional Aquaculture Center (NRAC) Fact Sheet No. 170

CCME: Canadian Council of Ministers of the Environment. 2001. Canadian water quality guidelines for the protection of aquatic life: CCME Water Quality Index 1.0, Technical Report. In: Canadian environmental quality guidelines, 1999. Winnipeg: Canadian Council of Ministers of the Environment. 14pp.

Chougule, M.B., Wasif, A.I. \& Naik, V.R. 2009. Assessment of water quality index (WQI) for monitoring pollution of Estuary Panchganga at Ichalkaranji. Proc. Int. Conf. Energy Environment. 122-127 pp.

Guasmi, I., Kherici-Bousnoubra, H., Kherici, N. \& Hadji, F. 2010. Assessing the organic pollution of surface water of Medjerda watershed (NE Algeria). Environ. Earth Sci. 60:985-992.
Kouame, M.K., Gnagne, T., Konan, F.K., Bony, Y.K. \& Gourene, G. 2012. Effects of treated agroindustrial effluents on physical and chemical characteristics of the receiving stream Wawa in south-eastern Côte d'Ivoire. Int. J. Biol. Chem. Sci. 6(2): 871-886

Krika, A. \& Krika, F. 2017. Assessment of surface water quality of Mencha Estuary (North Eastern Algeria) by index method. Caspian J. Environ. Sci. 15(12):157-146

Leclercq, L. \& Maquet, B. 1987. Deux nouveaux indices chimique et diatomique de qualitéd'eau courante. Application au Samson et à sesaffluents (Bassin de la Meuse belge). Comparaison avec d'autres indices chimiques, biocénotique set diatomiques, Editions Institutroyale Sciences de la Nature Belge, 1-113 pp

Lind, O.T. 1979. Handbook of common method in limnology, $2^{\text {nd }}$ edition. C.V. Mosby Co., ST. Louis. $199 \mathrm{pp}$.

Pesce, S.F. \& Wunderlin, D.A. 2000. Use of water quality indices to verify the impact of Coardoba City (Argentina) on Suquoaa Estuary. Water Res. 34(11):2915-2926

Pradeep, V., Deepika, C., Urvi, G., \& Hitesh, S. 2012. Water Quality Analysis of an Organically Polluted Lake by Investigating Different Physical and Chemical Parameters. Int. J. Res. Chem. Environ. 2(1):105-111.

Rahul, U., Arvind, P.K. \& Upadhyay, S.K 2013. Assessment of Lake Water Quality by Using Palmer and Trophic State Index- a Case Study of Upper Lake, Bhopal, India. Int. Res. J. Environ. Sci. 2(5):1-8.

Samantray, P., Mishra, B.K., Panda, C.R. \& Rout, S.P. 2009. Assessment of water quality index in Mahanadi and Atharabanki Estuarys and Taldanda canal in Paradiparea, India. J. Hum. Ecol. 26 (3):153-161.

Simões, F., Moreira, A.B., Bisinot, M.C., Gimenez, S.M. \& Yaba, M.J. 2008. Water quality index as a simple indicator of aquaculture effects on aquatic bodies. Ecol. Indicator, 8:476-484.

Strickland, J.D.H. \& Parsone, T. R. 1972. Apractical hand book of seawater analysis. $2^{\text {nd }}$ Ed. Bull. Fish. Res. Bd. Can. 167 pp. 
Varol, M., Gökot, B., Bekleyen, A. \& Șen, B. 2011. Water quality assessment and apportionment of pollution sources of Tigris Estuary (Turkey) using multivariate statistical techniques - A case study. Estuary Res. Appl. published online in Wiley Online Library. (Wileyonlinelibrary.com) DOI: $10.1002 /$ rra. 1533. 